\title{
NILAI-NILAI PENDIDIKAN AGAMA ISLAM MULTIKULTURAL DALAM DUNIA TAREKAT
}

\author{
Oleh: Halimatussa'diyah \\ Pondok Pesantren Darul'Ulum Jombang
}

Email : halimatus@gmail.com

\begin{abstract}
Abstrak
Nilai-nilai pendidikan Agama Islam multikultural dalam Tarekat ini di Implementasikan dalam kegiatan beribadah dan muamalah oleh pengikut Tarekat maupun masyarakat yang tidak ikut Tarekat. Adapun pengaruh Tarekat di dua desa tersebut memberi pengaruh positif terhadap kehidupan sosial dimasyarakat, yang meliputi tiga aspek yaitu spiritual, sosial dan ekonomi. Dengan memunculkan perilaku dan sikap yang baik, mentaati norma-norma yang ada, menjalin hubungan yang harmonis dari segi apapun baik dari segi, sosial dan ekonomi dan kemaslahatan lainnya. Aktif dalam bidang spiritual semakin menambah ketakwaan diri kepada Allah. Dengan demikian Tarekat di dua tempat semakin maju dari tahun-ketahun setelah adanya ajaran pendidikan agama Islam.
\end{abstract}

Kata kunci: nilai-nilai, Islam, multikultural, tarekat

\section{Abstract}

The values of multicultural Islamic education in this Tarekat are implemented in worship and muamalah activities by followers of the Tarekat and the people who do not participate in the Tarekat. The influence of the Tarekat in the two villages has a positive influence on social life in the community, which includes three aspects, namely spiritual, social and economic. By raising good behavior and attitudes, adhering to existing norms, establishing harmonious relationships in any aspect both in terms of social and economic and other benefits. Being active in the spiritual field increasingly adds to one's devotion to God. Thus the Tarekat in two places progressed from year to year after the teachings of Islamic religious education.

Keywords: values, Islamic, multicultural, tarekat

\section{PENDAHULUAN}

Penduduk yang berdomisili di sekitar Pesantren Darul'Ulum hidup dengan keakraban, kedamaian, toleransi satu sama lain. Keharmonisan antara keluarga besar Pondok Pesantren Darul'Ulum dengan masyarakat setempat terlihat saat kegiatan sewelasan berlangsung, terlihat para jama'ah berbagai masyarakat baik dari kota Jombang maupun luar kota Jombang 
bahkan dari luar jawa mereka berbondong-bondong berbaris menuju makam sesepuh Tarekat Qodiriyah Wa Naqsyabandiyah untuk mengikuti tradisi "sewelasan" bersama seluruh warga Desa Rejoso.

Selanjutnnya Tarekat Qodiriyah Wa Naqsyabandiyah di Pondok Pesantren Darul'Ulum memiliki keunikan dibandingkan dengan Tarekat lain. salah satu anggota Tarekat asal Kediri yang kebetulan sedang membesuk putrinya di asrama 1 Al-masyhari mengatakan pada peneliti yang saat itu lagi ngobrol di ruang tamu Pondok Darul'Ulum, selain tempatnya yang ramai, dekat dengan jantung kota, biaya jadi anggota Tarekat cukup lima belas ribu rupiah seumur hidup tetapi kualitas spiritualnya tidak kalah dengan Tarekat lainnya di Kabupaten Jombang. Selain itu kekompakan para Majelis Pondok yang membuat Tarekat ini semakin eksis. Jika di Tarekat lain satu pesantren diasuh oleh satu Kyai, tapi di Darul'Ulum diasuh oleh tujuh Kyai Majelis Pondok, tujuh Kyai majelis pondok tersebut bersaudara dari tiga bani, yaitu bani Cholil, bani Romli dan bani Umar yang mempunyai tupoksi masing-masing sesuai keahliannya. Selain itu dukungan masyarakat sekitar yang sangat membantu perkembangan Tarekat Qodiriyah Wa naqsyabandiyah tersebut.

Keunikan lain yang dimiliki Tarekat ini menurut ibu Masruroh yang merupakan jama'ah Tarekat berasal dari Kediri (informan B.01) yaitu setiap malam di masjid Induk diadakan jama'ah shalat tahajud dilanjut dengan baca dzikir Qodiriyah dan Naqsyabandiyah yang dimulai pada pukul 12.30 malam, para jama'ah Tarekat yang bermukim di Pondok mereka terdiri dari hidup sendirian, ditinggal suami selingkuh, banyak hutangnya, tidak diurusi putra putrinya, depresi, serta orang-orang yang bangkrut dalam usahanya. Mereka diajak untuk intropeksi diri dan lebih mendekatkan diri pada Allah supaya hidupnya lebih berkah.

Salah satu keunikan di ndalem kesepuhan atau ndalem pendiri Tarekat Rejoso yakni Kyai H. Romli Tamim. Konon Ibu Nyai Romli Tamim (isteri Kyai Romli Tamim) yang panggilan akrabnya dengan sebutan Mbah ibu selain pandai dalam ilmu ladunni, beliau juga memiliki amalan puasa Ya man huwa. Para santri, para jama'ah Tarekat yang diijazahi amalan puasa tersebut, maka atas ridho Allah dapat membuka mata batin dan lamakelamaan dapat mencapai ilmu ma'rifat.

Tarekat Naqsyabandiyah Kholidiyah Mujadadiyah Al Aliyah Dusun Kapas Dukuh Klopo Peterongan Jombang yang telah melakukan inovasi dibeberapa dimensi, yaitu dimensi olahrogo, olah pikir, olah kalbu dan olah laku. Inovasi-inovasi tersebut dijalankan secara pelan tapi pasti, dengan mengaplikasikan sebuah kaidah al-Muhafadhat 'ala al-Qodim al-Salih wa al-Alhdz bi al-Jadid al-Aslah yang secara bebas dimaknai sebagai upaya "menjaga sesuatu yang lama (klasik) yang positif, sambil mengadopsi 
sesuatu yang baru yang lebih actual dan positif" sehingga membuat Tarekat Naqsyabandiyah Kholidiyah Mujadadiyah Al Aliyah Dusun Kapas Dukuh Klopo Peterongan Jombang tetap bertahan sebagai bagian integral tradisi Islam di Indonesia.

Berangkat dari dalam paparan konteks di atas, maka tepat apabila peneliti mengangkat tema Nilai-Nilai pendidikan Agama Islam Multikultural Dalam Tarekat sekaligus sebagai landasan peneliti untuk mengungkap dan mengkaji tentang proses membina keberagaman melalui untaian Nilai-nilai Pendidikan Agama Islam multikultural pada kedua lembaga Tarekat, serta menelisik sejauh mana kontribusi nilai-nilai pendidikan agama Islam multikultural dalam membentuk komunitas Tarekat untuk berpikiran terbuka, inklusif dan moderat.

\section{METODE PENELITIAN}

Penelitian yang digunakan kajian ini adalah penelitian kualitatif, jenisnya metode penelitian etnografis, menurut teori Bernard dan Creswell bahwa etnografi merupakan kegiatan pengumpulan data untuk mendeskripsikan manusia atau budaya, disebabkan oleh kenyataan bahwa yang dikaji adalah implementasi pendidikan agama Islam multikultural dalam Tarekat. Untuk dapat mengungkap hal-hal tersebut di atas, pada bab III ini akan diuraikan secara berurutan tentang pendekatan dan jenis penelitian, kehadiran peneliti, penetapan lokasi, subyek penelitian, fokus dan pertanyaan penelitian, teknik pengumpulan data, dan teknik analisa data.

Sesuai dengan judul dan fokus penelitian, maka Pendekatan yang dipakai dalam penelitian ini adalah pendekatan kualitatif. Bogdan dan Taylor, mengungkap bahwasannya metodologi penelitian kualitatif adalah sebagai prosedur penelitian yang menghasilkan data diskriptif kualitatif: ucapan atau tulisan dan perilaku yang dapat diamati dari orang-orang (subyek) itu sendiri. Pendekatan tersebut langsung menunjukkan setting dan individu-individu dalam setting tersebut secara keseluruhan; subyek pendidikan, baik organisasi maupun individu tidak dipersempit menjadi komponen yang terpisah, melainkan sebagai bagian dari keseluruhan. Penelitian kualitatif ini bersifat inkuiri naturalistik atau alamiah, etnografi, interaksionis simbolik, perspektif ke dalam, etnometodologi, fenomenologis, studi kasus, interpretative, ekologis, dan deskriptif (Bogdan dan Biklen, 1982) ${ }^{1}$

${ }^{1}$ Lexi J.Moleong, Metodologi penelitian Kualitatif (Bandung: PT Remaja Rosdakarya 2014), 3. 
Sumber data penelitian ini adalah primer, sekunder, dan pelengkap Untuk memperoleh data dalam penelitian ini, peneliti menggunakan teknik pengumpulan data dengan alur pemikiran Bogdan dan Biklen (1982) yang meliputi observasi partisipatif, wawancara mendalam, dan studi dokumentasi secara menyeluruh. ${ }^{2}$ Penelitian ini menggunakan teknik analisis data seperti yang dikembangkan oleh (Miles \& Huberman, 1984) ${ }^{3}$ yang pada dasarnya analisis data selama pengumpulan itu merupakan analisis awal terhadap data yang diperoleh. Analisinya dapat diupayakan dengan apa yang disebut kegiatan reduksi data (data reduction).

\section{PEMBAHASAN}

Sebelum membahas tentang nilai-nilai pendidikan Islam multicultural Dalam Tarekat Qodiriyah Wa Naqsyabandiyah Rejoso Peterongan dan Tarekat Naqsyabandiyah Kholidiyah Mujadadiyah al Aliyah Kapas Dukuhklopo Peterongan Jombang, perlu dipahami beberapa hal yang berkaitan dengan soal ini:

Pertama, nilai dan multicultural. Nilai dilihat dari segi bahasa Inggris value, bahasa latin valare atau bahasa Prancis Kuno valoir yang dimaknai sebagai harga. Hal ini selaras dengan definisi nilai pada umunya yang diartikan sebagai harga (dalam arti taksiran harga). Namun kalau kata tersebut sudah dihubungkan dengan suatu obyek atau dipersepsi dari suatu sudut pandang tertentu, harga yang terkandung didalamnya memiliki tafsiran yang bermacam-macam. Harga suatu nilai hanya akan menjadi persoalan ketika hal itu diabaikan sama sekali, sehingga manusia dituntut untuk menempatkannya secara seimbang atau memaknai harga-harga lain, sehingga manusia diharapkan berada dalam tatanan nilai yang melahirkan kesejahteraan dan kebahagiaan.

Apabila kita melihat pengertian nilai secara umum, nilai sering diartikan sebagai sebuah harga. Dalam sebuah laporan yang ditulis oleh $A$ Club of Rome (UNESCO) nilai diuraikan dalam dua gagasan yang saling berseberangan. Disatu sisi, nilai dibicarakan sebagai nilai ekonomi yang disandarkan pada nilai produk, kesejahteraan, dan harga, dengan penghargaan yang demikian tinggi padahal yang bersifat material. Sementara di lain hal, nilai digunakan untuk mewakili gagasan atau makna yang abstrak dan tak terukur itu, antara lain keadilan, kejujuran, kebebasan, kedamaian, dan persamaan. Dikemukakan pula, system nilai merupakan sekelompok nilai yang saling berkaitan satu dengan lainnya dalam sebuah system yang saling menguatkan dan tidak terpisahkan. Nilai- nilai itu

${ }^{2}$ M.Djunaidi Ghony, Proposal Penelitian (Malang: UNISMA 2016), 30.

${ }^{3}$ Masykuri Bakri, Metode Penelitian kualitatif Tinjauan teoritis dan praktis (Malang: Visipress Media, 2013), 177. 
bersumber dari agama maupun dari tradisi humanistik. Nilai adalah alat yang menunjukkan alasan dasar bahwa "cara pelaksanaan atau keadaan akhir tertentu lebih disukai secara sosial dibandingkan cara pelaksanaan atau keadaan akhir yang berlawanan, hal ini untuk mengetahui sejauh mana suatu program berhasil diterapkan. ${ }^{4}$ Nilai memuat elemen pertimbangan yang membawa ide-ide seorang individu mengenai hal-hal yang benar, baik, atau dinginkan. Berikut ini akan dikemukakan beberapa pengertian nilai menurut para ahli sebagai berikut:

a. Menurut Spranger bahwa nilai adalah suatu tatanan yang dijadikan panduan oleh individu untuk menimbang dan memilih alternative keputusan dalam situasi sosial tertentu. ${ }^{5}$ Nilai yang merupakan sebuah bahasan yang ada dalam sebuah filsafat dimana nilai merupakan salah satu cabang dari filsafat yang disebut dengan aksiologi atau filsafat nilai. Nilai merupakan sebuah landasan ataupun alasan dalam sebuah tingkah laku dan sikap, baik yang dilakukan secara sadar ataupun tidak.

b. Menurut Kupperman (Mulyana;2004:9) Nilai adalah patokan normative yang mempengaruhi manusia dalam menentukan pilihan diantara cara-cara tindakan alternatif. Penekanan utama definisi ini pada faktor eksternal yang mempengaruhi prilaku manusia. Pendekatan yang melandasi definisi ini adalah pendekatan sosiologis. Penegakan norma sebagai tekanan utama dan terpenting dalam kehidupan sosial akan membuat seseorang menjadi tenang dan membebaskan dirinya dari tuduhan yang tidak baik.

c. Menurut Kluckhon (Mulyana,2004:10) Nilai adalah konsepsi (tersurat atau tersirat,yang sifatnya membedakan individu atau ciriciri kelompok) dari apa yang diinginkan, yang mempengaruhi tindakan pilihan terhadap cara, tujuan antara dan tujuan akhir. Definisi yang dikemukakan oleh Klukhon ini berimplikasi terhadap pemaknaan nilai-nilai budaya, seperti yang diungkap oleh Brameld dalam bukunya tentang landasan-landasan budaya pendidikan, dia mengungkapkan ada enam implikasi terpenting yaitu sebagai berikut:

\footnotetext{
${ }^{4}$ Suharsimi Arikunto,Dasar-dasar Evaluasi pendidikan Edisi 2, (Jakarta: Bumi Aksara 2015), 19.

${ }^{5}$ www.Pengertianpakar.com/2015/03/pengertian -nilai-dan macam-macam nilai.html, akses 15 Mei 2019.
} 
1) Nilai merupakan konstruksi yang melibatkan proses kognitif (logis dan rasional) dan proses ketertarikan dan penolakan menurut kata hati.

2) Nilai selalu berfungsi secara potensial, tetapi selalu tidak bermakna apabila diverbalisasi.

3) Apabila hal itu berkenaan dengan budaya, nilai diungkapkan dengan cara yang unik oleh individu atau kelompok.

4) Karena kehendak tertentu dapat bernilai atau tidak, maka perlu diyakini bahwa pada dasarnya disamakan (equated) dari pada diinginkan.

5) Pilihan di antara nilai-nilai alternative dibuat dalam konteks ketersediaan tujuan antara (means) dan tujuan akhir (ends)

6) Nilai itu ada, ia merupakan fakta alam, manusia, budaya dan pada saat yang sama ia adalah norma-norma yang telah disadari.

d. menurut Lasyo. Bahwa nilai bagi manusia merupakan landasan atau motivasi dalam segala tingkah laku atau perbuatan.

e. Menurut Cheng. Nilai merupakan sesuatu yang potensial dalam arti terdapatnya hubungan yang harmonis dan kreatif, sehingga berfungsi untuk menyempurnakan manusia, sedangkan kualitas merupakan atribut atau sifat yang seharusnya dimiliki.

f. menurut Gordon Allfort (Mulyana, 2004) Bahwa nilai adalah keyakinan yang membuat seseorang bertindak atas dasar pilihannya.

Definisi ini dilandasi oleh pendekatan psikologis, karena itu tindakan dan perbuatannya seperti keputusan benar-salah, baik buruk,indah-tidak indah, adalah hasil. Proses psikologis termasuk kedalam wilayah ini seperti hasrat, sikap, keinginan, kebutuhan dari beberapa pengertian tentang nilai dapat disimpulkan bahwa nilai adalah salah satu dari macam-macam nilai yang mendasari perbuatan seseorang atau sekelompok orang atas dasar pertimbangan kepercayaan bahwa sesuatu itu dipandang benar menurut agama, yaitu yang mengandung tuntutan untuk dikerjakan atau ditinggalkan. ${ }^{6}$

${ }^{6}$ Tim kajian Keislaman Nurul ilmi, Buku induk Terlengkap Agama islam,(Yogyakarta:Citra Risalah,2012).146. 
Secara etimologi multikultural terdiri atas kata "multi" yang berarti banyak atau beranekaragaman, dan kultural yang berarti budaya. Jadi pengertian multikultural secara sederhana adalah sebagai keragaman atau perbedaan terhadap suatu kebudayaan yang lain. Selanjutnya multikultural adalah istilah yang digunakan untuk menggambarkan pandangan seseorang tentang berbagai kehidupan di bumi, atau kebijakan yang menekankan penerimaan keragaman budaya, dan berbagai budaya nilai-nilai (multikultural) masyarakat, budaya, adat istiadat, dan politik yang mereka pegang.

Kedua, Muhaemin el Ma'hady berpendapat, bahwa secara sederhana pendidikan multikultural dapat didefinisikan sebagai pendidikan tentang keragaman kebudayaan dalam meresponi perubahan demografis dan kultural lingkungan masyarakat tertentu atau bahkan dunia secara keseluruhan (global). ${ }^{7}$ Menurut Har Tilaar (2002), pendidikan multikultural berawal dari berkembang gagasan dan kesadaran tentang "Interkulturalisme" seusai perang dunia II. Kemunculan gagasan dan kesadaran "Interkulturalisme" ini selain terkait dengan perkembangan politik internasional diskriminasi rasial dan lain-lain, juga karena meningkatkan pluralitas (keberagaman) di Negara-negara barat sendiri sebagai akibat dari peningkatan migrasi dari Negara-negara baru merdeka ke Amerika dan Eropa. Mengenai fokus pendidikan multikultural, Tilaar mengungkapkan bahwa dalam program multikultural, fokus tidak lagi diarahkan semata-mata kepada kelompok rasial cultural domain atau mainstream. Fokus seperti ini memang pernah menjadi tekanan pada pendidikan multikultural yang meningkatkan pemahaman dan toleransi individual-individual yang berasal dari kelompok minoritas terhadap budaya mainstream yang dominan, yang pada akhirnya menyebabkan ke dalam masyarakat mainstream. ${ }^{8}$

Ketiga, Pendidikan Agama Islam sering diartikan secara sempit yaitu merupakan upaya melalui berbagai kegiatan belajar agar ajaran agama Islam dapat dijadikan pedoman bagi hidupnya. Pada sisi lain secara luas seperti yang dikatakan di atas Pendidikan Agama perlu diartikan sebagai usaha sadar untuk mengarahkan pertumbuhan dan perkembangan manusia dengan segala potensi yang dianugerahkan Allah kepadanya agar mampu mengemban amanat dan tanggung jawab sebagai khalifah Allah di bumi 2005), 176 .

${ }^{7}$ Choirul Mahfud, pendidikan Multikultural,(Yogyakarta: pustaka pelajar offset,

${ }^{8}$ Muhammad Tholchah Hasan, Pendidikan Multikultural Sebagai Opsi Penanggulangan radikalisme, (Malang:UNISMA 2016),29. 
dalam pengabdiannya kepada Allah SWT. Tujuan dimaksudkan agar manusia mampu mengolah dan menggunakan segala kekayaan yang ada di langit dan di bumi untuk kesejahteraan dan kebahagiaan hidup di akhirat kelak. Gambaran manusia yang diharapkan melalui proses pendidikan Agama yang demikian adalah seorang muslim yang beriman kepada Allah, bertakwa, berakhlak mulia, beramal kebaikan(amal saleh) menguasai imtek (untuk dunia dan akhirat) dan menguasai ketrampilan dan keahlian agar dapat memikul amanah dan tanggung jawab yang dibebankan kepadanya sesuai dengan kemampuan masing-masing. ${ }^{9}$

a. Al-Abrasyi memberikan pengertian bahwa tarbiyah adalah mempersiapkan manusia supaya hidup dengan sempurna dan bahagia, mencintai tanah air, tegap jasmaninya, sempurna budi pekertinya (akhlaknya), teratur pikirannya, halus perasaannya mahir dalam pekerjaannya, manis tutur katanya baik dengan lisan atau tulisan. AlAbrasyi menekankan pencapaian kesempurnaan dan kebahagian hidup.

b. Hasan Langgulung mengatakan, bahwa "pendidikan Agama Islam adalah proses penyiapan generasi muda untuk mengisi peranan, memindahkan pengetahuan dan nilai-nilai Islam yang diselaraskan dengan fungsi manusia untuk beramal di dunia dan memetik hasilnya di akhirat.

c. Omar Mohammad al-Thumi Al-Syaibani, menyatakan bahwa Pendidikan Islam adlah proses mengubah tingkah laku individu pada kehidupan pribadi, masyarakat dan alam sekitarnya dengan cara pengajaran sebagai suatu aktifitas asasi dan sebagai profesi di antara profesi-profesi asasi dalam masyarakat.

d. Rumusan konferensi Pendidikan Islam sedunia yang ke 2, pada tahun 1980 di Islamabad, bahwa Pendidikan Agama Islam harus ditujukan untuk mencapai keseimbangan pentumbuhan personalitas manusia secara menyeluruh, dengan cara melatih jiwa, akal, perasaan, dan fisik manusia. Dengan demikian pendidikan diarahkan untuk mengembangkan manusia pada seluruh aspeknya: spiritual, intelektual, daya imajinasi, fisik, keilmuan dan bahasa, baik secara individu maupun kelompok untuk mencapai kebaikan dan kesempurnaan. ${ }^{10}$

M.Yusuf al-Qardhawi menyebut, bahwa pendidikan Islam adalah pendidikan manusia seutuhnya, akal dan hatinya, rohani dan jasmaninya, akhlak dan ketrampilannya. Karena itu, pendidikan Agama Islam

${ }^{9}$ Abdul Rachman Shaleh, Pendidikan Agama Dan Keagamaan Visi,Misi dan Aksi (Jakarta: PT Gemawindu Pancaperkasa, 2000), 5.

${ }^{10}$ Ramayulis, Ilmu Pendidikan Islam, (Jakarta: Kalam Mulia, 2015), 37. 
menyiapkan manusia untuk hidup baik dalam keadaan damai maupun perang, dan menyiapkannya untuk menghadapi masyarakat dengan segala kebaikan dan kejahatannya, manis dan pahitnya. ${ }^{11}$

Berdasarkan hal itu, maka pendidikan Agama Islam adalah merupakan satu-satunya lembaga pendidikan yang ada di Indonesia berlandaskan kepada beberapa hal, yaitu : pertama, landasan spiritual, yang berupa nilai-nilai yang terkandung dalam Al-Qur'an dan Sunnah Rasulullah. Kedua, landasan filosofis yang berupa kurikulum, yang dalam pengertian luas merupakan produk ijtihad yang dapat meliputi seluruh aspek kependidikan. Ketiga, landasan operasional yang meliputi berbagai didaktik metodik, dana dan sarana serta leadership dan manajemen. Sehingga penting menjadikan Pendidikan Agama Islam sebagai salah satu pendidikan alternative, tentunya dengan membutuhkan paradigm-paradigma baru untuk meningkatkannya, antara lain dengan peningkatan manajemen pendidikan Islam itu sendiri.

Islam itu mengacu kepada suatu pengertian bahwa yang dimaksud dengan Pendidikan Agama Islam adalah upaya membimbing, mengarahkan, dan membina secara sadar dan terencana agar terbina suatu kepribadian yang utama sesuai dengan nilai-nilai Islam. Tujuan ini secara hirarkis bersifat ideal, bahkan universal. Tujuan tersebut dapat dijabarkan pada tingkat yang lebih rendah lagi, menjadi tujuan yang bercorak nasional, institusional, terminal, klasikan, perbidang, per pokok ajaran, sampai dengan setiap kali melaksanakan kegiatan belajar mengajar. ${ }^{12}$

Keempat, dalam kitab jami'ul ushul fil Auliya' karya Syaikh Ahmad Al-kamsyakhanawi An-Naqsyabandi disebutkan Tarekat menurut tasawuf adalah laku tertentu bagi orang-orang yang menempuh jalan kepada Allah, berupa memutus/meninggalkan tempat-tempat hunian dan naik ke maqam/tempat-tempat mulia. Adapun menurut Ali Al-Jurjani (740-816 M), Tarekat ialah metode khusus yang dipakai oleh salik (para penempuh jalan) menuju Allah Swt melalui tahapan-tahapan (maqamat). Saiyid bakri al Makky bin Muhamad al-Syatho al-Dimyathi, mengatakan melalui beberapa syairnya jalan tembus menuju akhirat harus ditempuh melalui tiga jalur: "Syariat, Tarekat, dan hakikat". Syariat ialah melakukan sepenuh hati agama Allah, dengan jalan melaksanakan perintah-perintah dan meninggalkan laranganNya.Tarekat ialah melaksanakan pengamalan syariat dengan ketelitian dan berhati-hati, seperti zuhud, sabar, tawakal, tobat, dan tidak melakukan hal-hal yang rendah dan rukhsah, sedangkan hakikat ialah tercapainya tujuan seorang salik untuk makrifat billah, dan pencerahan

${ }^{11}$ Azyumardi Azra, Pendidikan Islam Tradisi dan Modernisasi Menuju Milenium Baru (Jakarta: Logos Wacana Ilmu 2002), 4.

${ }^{12}$ Abuddin Nata, Metodologi Studi Islam, (Jakarta: Rajawali Pers, 2016), 340. 
spiritual, menerawang penampakan, tajaali sifat-sifat dan afal Allah. ${ }^{13}$ Dalam hal ini Tarekat sebagai wadah kelompok orang-orang yang mengkhususkan diri dalam suluk ke hadirat Allah, berkembang biak menjadi puluhan, bahkan ratusan jumlahnya.

\section{Nilai Kedisiplinan}

"Shalat yang dilakukan dengan ketaatan dan kepatuhan terhadap peraturan-peraturan (hukum) perintah dalam kedisiplinan shalat berjama'ah yang diterapkan pada Tarekat Qodiriyah Wa Naqsyabandiyah Rejoso Peterongan dan Tarekat Naqsyabandiyah Kholidiyah Mujadadiyah al Aliyah Kapas Dukuhklopo Peterongan Jombang.

Menurut peneliti tentang aspek kedisiplinan shalat berjama'ah adalah: ketetapan waktu dalam shalat.Dalam shalat dituntut adanya kesediaan untuk melaksanakannya sesuai dengan waktu yang telah ditentukan. Karena waktu-waktu shalat yang telah diatur itu merupakan peringatan bagi kaum muslimin agar dalam hidupnya berlaku disiplin dann menghargai waktu serta tidak menyia-yiakannya untuk berbuat yang tak berguna.

\section{Nilai Tanggung Jawab}

Sebuah perintah jika dilihat dari kasat mata mungkin mudah untuk melaksanakannya, namun jika ditelisiki lebih dalam perintah tersebut berbuah amanah yang akan dipertanggungjawabkan nanti di akhirat kelak, yaitu melaksanakan perintah shalat yang merupakan ibadah yang pertama kali dihisab dan dianalogikan sebagai tiang berdirinya agama Islam, sehingga lebih berat lagi tanggung jawab itu apabila jadi seorang imam dalam shalat berjama'ah. Menurut Kyai Shobih dengan panggilan akrabnya Gus Shobih menurut beliau: berdasarkan pendapat yang paling shahih, bahwa jabatan imam shalat bagi jama'ah Tarekat paling baik dimanfaatkan kepada yang paling mampu memikulnya. Karena itu, Rasulullah senantiasa menjadi imam karena beliaulah yang paling mampu memikul tanggung jawabnya.

\section{Al-Amanah}

menurut peneliti, sebelum seseorang terjun untuk bersyari'at dan bertasawuf, dia harus memperkokoh dirinya dengan nilai-nilai keimanan (tauhid) kepada Tuhan, sehingga kelak semua amal ibadahnya, baik yang bersifat eksoterik (sya'riat) maupun yang bersifat esoteric (tasawuf) hanya diperuntukkan kepada Tuhan. Tidak sedikit sufi yang dalam perjalanan

${ }^{13}$ Machfould Harim, Tasawuf Praktis tanpa Tarekat dan Mursyid, (Jombang: Rejoso Med, 2011), 72. 
kesufiannya kemudian terjerumus pada perilaku dan tindakan aneh-aneh (jadab) dan beretentangan dengan dasar-dasar tauhid dan syari'at. Untuk itu, supaya seseorang tidak tersesat ketika masuk dunia Tarekat, harus diperkokoh terlebih dahulu dengan nilai-nilai Amanah.

\section{Nilai Ar-Rahma (Kasih Sayang)}

Pagi itu kira-kira pukul 7.30, Terlihat para jama'ah Tarekat berdatangan dari berbagai penjuru daerah mereka menuju Masjid Induk Pon.Pes Darul'Ulum mereka ada yang langsung mengambil air wudhu, yang ada di belakang persisi Masjid Induk, setelah itu mereka melangkahkan kakinya dengan tenang menuju ruangan masjid untuk melaksanakan sholatsholat sunah, diantaranya sholat takhiyatul masjid, sholat dhuha, setelah itu mereka dengan rasa kepedulian dan kasih sayang antara jama'ah Tarekat saling sapa, saling bersalaman untuk menghsilkan hubungansosial yang baik, menjalin persaudaraan, dan mempererat silaturrahmi

\section{Nilai Spiritual}

Menurut peneliti bahwa para sufi berbicara tentang sesuatu yang dinamakan dengan hal (kondisi spiritual sufitik), dan tentang sesuatu yang dinamakan dengan maqam, sebagai contoh diungkapkan Said Hawwa memandang bahwa hal pertama yang dipaparkan seseorang ketika sibuk dzikir adalah ketenangan sementara dalam hati yang bisa saja sirna, inilah disebut hal. Kemudian, jika dia terus menerus berdzikir maka dia akan sampai pada ketenangan hati yang bersifat langgeng, inilah disebut maqam.

\section{Nilai as -Salam (kedamaian)}

Filsafat perdamaian atau as-Salam dalam ajaran Tarekat mengisyaratkan tata nilai perdamaian sufistik yang dapat digunakan sebagai salah satu alternative atas involusinya paradigm perdamaian ilmu sosial yang selama ini menjadi rujukan dalam menyelesaikan konflik dan menciptakan perdamaian hidup manusia yang berinteraksi dengan diri, masyarakat, Negara, dan lingkungan alam ini.

\section{Nilai Sosial}

Dalam setiap individual mempunyai cara dan metode sendiri dalam proses menanamkan nilai-nilai sosial pada dirinya. Orang yang mengamalkan Tarekat Qodiriyah Wa Naqsyabandiyah tidak hanya memikirkan dirinya sendiri tetapi kasih sayangnya lebih besar terhadap orang lain antara lain:

a. Pengabdian terhadap masyarakat juga tidak terkalahkan oleh amalanamalan yang yang didapat dalam Tarekat. 
b. Kekeluargaan

Kekeluargaan pada Tarekat cukup rukun dan saling menjaga silaturrahim. Kerukunan dalam Tarekat yaitu mulai dari anak-anak sudah dilatih untuk hidup rukun apalagi orang-orang pengamal Tarekat mereka sebagai contoh untuk anak-anak dan masyarakat Rejoso Peterongan.

c. Kepedulian

Menurut peneliti tingkat kepedulian sosial pada Tarekat ini sangat tinggi, yaitu, seperti berbagi makanan kepada seluruh unit yang ada di Pondok Pesantren Darul'Ulum, dan tetangga sebelahnya, berbondong-bondong menjenguk waktu ada yang sakit, berbagi tenaga waktu ada khajatan di tetangga sebelah. Masyarakat Tarekat ini cara menerapkan tingkah laku seperti ini pada waktu masih kanak-kanak sampai mereka sudah tua, tingkat kepedulian terhadap tetangga cukup tinggi. Walaupun hanya sekedar menyapa atau membantu tetangga yang sedang kesulitan.

\section{Nilai Kebersamaan}

Menurut peneliti amaliah jama'i, yang berintikan kebersamaan adalah penunjang amalia individual. Dimulai shalat fardhu berjama'ah, wirid, dzikir dan baca do'a, membaca sholawat dan tausyia, serta pengajian kitab kuning .

\section{Nilai At-Tasamuh (toleransi)}

Menurut peneliti Tarekat mengajarkan bahwa sesama jama'ah Tarekat harus bersatu serta tidak boleh bercerai-berai, bertengkar, dan bermusuhan. Karena jama'ah Tarekat adalah saudara akan mempererat silaturrahmi sebagai salah satu kekuatan dalam menjaga persatuan ditengah umat. Kegiatan sewelasan pada tanggal 11 Robi'ul Akhir atau bertepatan tanggal 18 Desember Tahun 2018. Pagi itu kira-kira pukul 7.30, Terlihat para jama'ah Tarekat berdatangan dari berbagai penjuru daerah mereka menuju Masjid Induk tempat jama'ah Tarekat melaksanakan segala aktifitas Tarekat, mereka berjalan berdesak-desakan, melintasi jalan yang dipingirnya penuh dengan orang jualan meskipun begitu mereka menahan diri untuk jalan pelan-pelan menuju lokasi, ada sebagian jama'ah Tarekat tidak langsung menuju lokasi kegiatan sewelasan, tapi mereka langsung menuju lokasi pesarean, itupun harus antri dengan sikap sabar dan saling menghargai dan tidak saling curiga.

\section{Nilai At-Ta'awun (saling tolong-menolong)}


Menurut peneliti didalam masyarakat Tarekat Rejoso Peterongan Jombang dan Tarekat Naqsyabandiyah Kholidiyah Mujadadiyah al Aliyah khususnya jama'ah Tarekat sangat mudah untuk tolong menolong yaitu seperti waktu ada kegiatan sewelasan dan lebonan mereka saling berbagi tempat, makanan ataupun kendaraan untuk berangkat ke acara rutin. persaudaraan lahir dan batin diwujudkan dalam bentuk tolong-menolong.

\section{Nilai Al-Musawah (Persamaan/Kesetaraan)}

Kegiatan Tarekat Qodiriyah wa Naqsyabandiyah dalam kegiatan mingguan yang diadakan tiap kamis, kegiatan sewelasan yang diadakan dalam satu tahun tiga kali kegiatan yaitu pada tanggal 11 Robi'ul Akhir, 10 Muharam dan Nisfu'Sya'ban. Pagi itu kira-kira pukul 10.00 Terlihat para jama'ah Tarekat dengan kondisi yang sehat serta wajah yang berseri-seri mereka menuju Masjid Induk tempat jama'ah Tarekat melaksanakan segala aktifitas Tarekat. Menurut informan B.2 di PPDU ada kegiatan yaitu pengajian kitab kuning yang dilaksanakan sebelum semua rangkaian kegiatan Tarekat dilaksanakan, jama'ah Tarekat mengikuti pengajian kitab kuning di pendopo, disini Bapak kyai tidak membeda-bedakan tentang kedudukan jama'ah Tarekat mereka semua sama yaitu persamaan dalam mengasuh kaweruh. Acara ini dilaksanakan setelah sholat dhuha berjama'ah sampai jam 11.30 siang, yang diikuti jama'ah kurang lebih berjumlah 500 jama'ah yang datang dari berbagai wilayah dengan tujuan untuk merajut persamaan dan penuh kesetaraan .

\section{Takafful Ijtima' (bakti sosial)}

Takaful Ijtima (bakti sosial) ditemukan pada kegiatan menjelang sewelasan berlangsung seperti kegiatan ro'an yang diselenggarakan oleh Tarekat Qodiriyah Wa Naqsyabandiyah serta kegiatan go clean and green, kegiatan tersebut melibatkan banyak jama'ah Tarekat. Contoh memasang terop dibeberapa titik tempat jama'ah, membersihkan Masjid, kamar-kamar mandi ataupun lingkungan sekitar dan menata bungah-bungah dengan membersihkan rumput-rumput di sekitar lokasi Tarekat Qodiriyah Wa Naqsyabandiyah. Para jama'ah tanpa memandang latar belakang ikut bahu membahu dalam kegiatan sewelasan tersebut. Begitu pula dalam kegiatan go clean and green yang diselenggarakan pada Tarekat Naqsyabandiyah Kholidiyah Mujadadiyah Al Aliyah, mereka bergotong royong menciptakan lingkungan yang bersih dan indah. Kegiatan-kegiatan ini merupakan kegiatan yang intinya berbakti baik kepada lingkungan Pesantren maupun masyarakat luar Pondok pesantren dengan cara gotong royong, bahu membahu, dan menciptakan suatu kehidupan yang harmoni. Kegiatan yang sudah merupakan tradisi pada jama'ah Tarekat adalah Sowanan. Tradisi 
jama'ah berkunjung kepada Kyai dengan harapan mendapatkan petunjuk atas sebuah permasalahan yang diajukannya, atau mengharapkan do'a dari Kyai atau sekedar bertatap muka silaturrahim saja. Sowan dapat dilakukan oleh jama'ah Tarekat secara individu atau bersama-sama. Dengan beberapa tradisi sewelasan Tarekat tersebut dapat meningkatkan dalam bidang perekonomian (Iqtishodiyah) masyarakat sekitar.

Kegiatan-kegiatan ini sinergi dengan Nilai-nilai Pendidikan Agama Islam Multikultural yakni menumbuhkan sikap hidup sederhana (Qana'ah), bekerja keras,gotong royong/harmoni (tawazun), bertanggung jawab (amanah), tolong menolong (tawazun) peduli sosial (takaful-al ijtima'), bekerjasama (ummatan wahidah), sikap hidup mandiri, saling menghormati (tasamuh), persamaan derajat (al-Musawwah), kemanusiaan (hablum minannas), dan sikap menghormati keberagaman (al-Tanawwu').

\section{Al-Insyirah}

Al-Insyirah merupakan sebuah konsep dalam suatu kegiatan atau wadah dalam membina keragaman untuk menggapai kebahagian hakiki dunia akhirat. Konsep ini bisa dijadikan paradigma meraih kesuksesan, keberhasilan, dan kebahagiaan hidup agar kita dapat menerima dengan lapang dada terkait hasilnya dalam kehidupan. Seperti di Tarekat Qodiriyah Wa Naqsyabandiyah banyak kegiatan Tarekat seperti pembelajaran kitab kuning (kitab hikam), pembelajaran dzikir (Bai'at), tahlil, manaqib, istighosah, dan lain-lain. Pada pembelajaran dzikir atau bai'at disini jama'ah di bai'at tidak sendiri melainkan dengan kebersamaan, pelajaran dzikir apa saja yang telah diajarkan oleh seorang Mursyid para jama'ah harus diterima dengan jiwa yang longgar dan lapang dada dan para jama'ah Tarekat dituntut untuk melakukan kegiatan atau aktivitas secara totalitas dan penuh kesungguhan. Contoh tentang jama'ah Tarekat dalam melakukan dzikir yang dilakukan lebih dahulu dzikir Qodariyah apabila sudah selesai beranjak ke aktivitas berikutnya yaitu pada Dzikir Naqsyabandiyah. Hal ini juga bermakna untuk melaksanakan ibadah dengan sungguh-sungguh ketika telah selesai melakukan berbagai urusan yang lain. Sebagai orang beriman maka sepatutnya kita hanya mengantungkan hasil akhir kepada Allah SWT kita terima dengan lapang dada.

Hal ini sesuai dengan konsep ajaran Islam yang terdapat dalam salah satu surat yang ada dalam Al-Qur'an yaitu surah Al-Insyirah: "Kelapangan" yang memerintahkan manusia untuk membaca dan mengamalkan dzikir apabila dibaca secara terus menerus dapat melapangkan hati orang yang membaca dan mendengarnya.

Implementasi nilai-nilai pendidikan agama Islam multikultural ajaran dalam Tarekat melalui dimensi olahrogo, olahkalbu, olahpikir, dan 
olahlaku. Dalam ajaran Tarekat ini lebih mengutamakan pada pengalaman olahkalbu, yaitu dzikir yang dilakukan oleh para pengikut di dalam rutinitas keagamaan sehari-hari. Sebab dzikir oleh para pengikut Tarekat adalah suatu perkara yang yang harus dilaksanakan dan merupakan kewajiban yang tidak boleh ditinggalkan dengan berdzikir juga berguna untuk selalu mengingat Allah agar senantiasa dapat mengontrol perbuatan-perbuatan kita supaya tidak melanggar ketentuan dan larangan dari Allah Swt.

Dalam hal ini perkara yang harus senantiasa diamalkan serta dilaksanakan oleh para pengikut Tarekat yaitu :

\section{Merawat Rogo (Olahrogo)}

Menurut peneliti istilah olahrogo dalam tradisi ajaran Tarekat berarti penyembuhan yang dapat memberikan keringanan bagi umat Islam. Ada tiga arti olahrogo definisi sembuh yaitu: pertama, sembuh dengan utuh dan baik. Kedua, tubuh dalam keadaan bebas dari penyakit baik dari luar maupun dalam. Ketiga, tubuh bebas dari segala bentuk keburukan. Penyembuhan sufi bearti sehat dalam segala aspek kehidupan manusia, termasuk dimensi fisik mental, emosional dan spiritual. Penyembuhan adalah menyadari kesempurnaan diri.

Di dalam diri kita terdapat unsur olahrogo dan olahkalbu atau unsur jasmani dan rohani yang mana kita sebagai ciptaan Allah yang ia ciptakan dengan sebaik-baiknya dan merupakan makhluk yang sempurna di antara ciptaan yang lainnya. Sehingga kita harus patuh kepada Allah, merawat rogo atau jasmani dan merawat kalbu atau rohani memberi hak-hak kepada diri kita membuat diri kita , memberi hak kepada diri kita untuk bergaul dengan orang lain, membantu orang lain, menciptakan akhlak yang baik, budi pekerti yang baik sehingga diri kita bermanfaat bagi sekitar kita.

\section{Menanamkan sikap Muraqabah atau olahpikir}

Olahpikir atau muroqabah merupakan kesadaran seseorang dalam segala keadaan berada dalam pengawasan Allah Swt merasa diri ini selalu diawasi oleh-Nya sehingga dalam melakukan tindakan atau perilaku selalu betul-betul berhati-hati karena kita tidak lepas dalam pengawasan-Nya. Kesadaran ini merupakan kesadaran murni yang berupa imajinasi dan daya khayal.

\section{Melaksanakan amalan dzikir (Olahkalbu)}

Seseorang harus yang telah mengikuti bai'at sudah resmi menjadi pengikut Tarekat dan harus siap melakukan amalan dengan istiqomah. Seperti halnya dzikir yang wajib diamalkan dan apabila ditinggalkan harus diganti di waktu yang lain. hal ini dijelaskan oleh Kyai Tamim ada beberapa amalam dzikir yang wajib untuk dilakukan yaitu dzikir yang dilakukan setelah sholat wajib atau lima waktu, yaitu: dzikir latifatul Qolbi, tempatnya dibawah dada bagian kiri, (di bagian bawah susu kiri), dzikir latifatul Rukhi, 
tempatnya dibawah dada bagian kanan, (dibagian bawah susu kanan), dzikir latifatul sirri, tempatnya di atas dada bagian kiri (diatas susu bagian kiri), dzikir latifatul khofi, tempatnya di atas dada bagian kanan (diatas susu bagian kanan), dzikir latifatul akhfa, tempatnya pas di dada bagian tengah, dzikir latifatul nafsi, tempatnya di otak bagian alis kiri, dzikir latifatul qalab, tempatnya mulai ujung kaki sampai rambut (seluruh anggota tubuh).

\section{Pengamalan dari segi olahlaku atau perilaku (akhlak)}

Dalam ajaran Tarekat ini mengajarkan tentang bagaimana seseorang harus olahlaku atau berperilaku yang baik kepada Allah, manusia, hewan dan lingkungan sekitar. Yang mana mencerminkan akhlak dan berbudi pekerti yang baik serta merupakan pengamalan yang harus dilaksanakan di dalam kehidupan sehari-hari, sebab dalam kita hidup tidak akan lepas dari semua itu

\section{PENUTUP}

Peneliti mengawali tulisan ini dengan menggunakan Teori utama Tarekat tasawuf (Al-Ghazali) serta teori Tazkiyah al-nafs yang dicetuskan oleh Said hawwa. Konsep yang dicetuskan oleh Al-Ghazali kajiannya mengenai kenyataan yang menunjukkan bahwa Tarekat pada intinya adalah perluasan dari tasawuf itu sendiri. Konsep Tarekat tasawuf yang dicetuskan oleh Al-Ghazali diimplementasikan kepada para jama'ah Tarekat melalui dimensi olahrogo, olahpikir, olahkalbu dan olahlaku. Pengenalan Islam serta indoktrinasi nilai-nilai Pendidikan Agama Islam Multikultural para jama'ah Tarekat Qodiriyah Wa Naqsyabandiyah dan Tarekat Naqsyabandiyah Kholidiyah Mujadadiyah Al Aliyah dilakukan secara menyeluruh tanpa mengorbankan norma yang telah berlaku di masyarakat.

Apa yang buruk dan tidak baik diubah perlahan-lahan tanpa harus menghormanikan harmoni di masyarakat. Sebaliknya, kebaikan yang sudah ada tinggal diselaraskan dengan nilai-nilai Pendidikan Agama Islam Multikultural. Konsep tazkiyah al-nafs dalam konteks Said Hawwa adalah membersihkan jiwa dari kemusyrikan dan cabang-cabangnya, merealisasikan kesuciannya dengan tauhid, dan menjadikan nama-nama Allah yang baik sebagai akhlak di samping ubudiyah kepadaNya dengan mencontoh dari Rasulullah SAW. Hasil dari Tarekat tasawuf ialah: pertama, Tarekat sebagai pendidikan keruhanian yang dilakukan oleh orang-orang yang menjalani kehidupan tasawuf, yang secara individu untuk mencapai suatu tingkat keruhanian tertentu, dan kedua, Tarekat sebagai sebuah perkumpulan atau organisasi yang didirikan menurut aturan yang telah ditetapkan oleh seorang syaikh yang menganut suatu aliran Tarekat tertentu.

\section{DAFTAR PUSTAKA}




\section{Buku}

Abdul Rachman Shaleh, 2000, Pendidikan Agama Dan Keagamaan Visi, Misi dan Aksi, Jakarta:PT Gemawindu Pancaperkasa.

Abuddin Nata, 2016, Metodologi Studi Islam, Jakarta: Rajawali Pers.

Azyumardi Azra, 2002, Pendidikan Islam Tradisi dan Modernisasi Menuju Milenium Baru, Jakarta:Logos Wacana Ilmu.

Choirul Mahfud, 2005, Pendidikan Multikultural, Yogyakarta: Pustaka Pelajar Offset, 2005.

Lexi J.Moleong, 2014, Metodologi penelitian Kualitatif Bandung: PT Remaja Rosdakarya.

Machfould Harim, 2011, Tasawuf Praktis tanpa Tarekat dan Mursyid, Jombang:Rejoso.

Masykuri Bakri, 2013, Metode Penelitian kualitatif Tinjauan teoritis dan praktis Malang:Visipress Media.

M.Djunaidi Ghony, 2016, Proposal Penelitian, Malang:UNISMA.

Muhammad Tholchah Hasan, 2016, Pendidikan Multikultural Sebagai Opsi Penanggulangan radikalisme, Malang:UNISMA.

Ramayulis, 2015, Ilmu Pendidikan Islam, Jakarta:Kalam Mulia.

Suharsimi Arikunto, 2015, Dasar-dasar Evaluasi pendidikan Edisi 2, Jakarta: Bumi Aksara .

Tim Kajian Keislaman Nurul ilmi, 2012, Buku induk Terlengkap Agama islam, Yogyakarta:Citra Risalah.

\section{Internet}

www.Pengertianpakar.com/2015/03/pengertian -nilai-dan macam-macam nilai.html, akses 15 Mei 2019. 